\title{
A Conceptual Framework to Classify Strategic Information Systems Planning Methodologies
}

\author{
Hadi Kandjani ${ }^{1}$, Amir Mohtarami ${ }^{2}$, Amirhossein Eslami Andargoli ${ }^{3}$ and Reza Shokoohmand ${ }^{4}$ \\ ${ }^{1,3}$ Centre for Enterprise Architecture Research and Management, School of ICT, Griffith University, Brisbane, Australia \\ ${ }^{2}$ Department of Information Technology Management, Tarbiat Modares University, Tehran, Iran \\ ${ }^{4}$ Department of Information Technology, Tehran Azad University, Tehran, Iran \\ H.Kandjani@griffith.edu.au,Mohtarami@modares.ac.ir,Amirhossein.Eslami-Andargoli@griffithuni.edu.au, \\ R.Shokoohmand@ieee.org
}

Keywords: Strategic Information Systems Planning, SISP methodology, Conceptual framework

Abstract: $\quad$ For many information systems executives, strategic planning for information systems continues to be a critical issue and remains a top concern of many organisations. Also, a comprehensive review of the recent IS planning literature reveals that selecting a proper methodology used in developing an information systems plan is one of the success factors related to the success of the IS planning process. Although this individual success factor should have attracted more research and discussions, there have not been enough attempts to create a framework to compare and classify strategic information systems planning methodologies to select a proper method for a specific organisation with its unique requirements. The purpose of this paper is primarily theoretical and is to propose a conceptual framework to classify strategic information systems planning methodologies to choose the suitable methodology(ies) according to the specific given requirements of an organisation.

\section{INTRODUCTION}

Strategic information systems planning (SISP) is essential for organisations to succeed (Newkirk, Lederer, \& Srinivasan, 2003). It is a continuous exercise that enables organisations to develop priorities for information system (IS) development. IS strategies are defined for their alignment with business objectives or their capacity to create significant impact on the organisation's competitive positioning.

Therefore, improving SISP practice as one of the most critical issues facing IS executives has been critically studied through the last two decades and continues to be a critical issue and remains a top concern of many organisations (Doherty, Marples, \& Suhaimi, 1999; Moynihan, 1990; Peppard \& Ward, 2004; J. Ward \& Peppard, 2002).

A comprehensive review of the IS planning literature reveals that the following factors are related to the success of the IS planning process (Doherty et al., 1999):

1. the need to align corporate objectives and IS strategy (Henderson \& Venkatraman, 1993);
2. the underlying motivation for the initialisation of the planning process (Banker, Kauffman, \& Morey, 1990);

3. the assessment model of Business-IT alignment of the organisation (Luftman, 2004);

4. the selection of a methodology used in developing the IS plan (Bergeon, 1991; A. Lederer \& Sethi, 1988; A. Lederer, Sethi, V., 1998)

5. the framework used for setting IT investment priorities (Burch, 1990);

6. the measurement of effectiveness used for the IS department (Clark Jr, 1992);

7. preparation of an implementation plan to meet SISP objectives (A. Lederer \& Sethi, 1996).

Although the fourth success factor should have attracted more research and discussions, there have been only a few attempts to create a framework to compare and classify SISP methodologies. The proliferation of methods and the variations in satisfaction indicate a need to provide guidance to assess the appropriateness of different approaches and the applicability of using several approaches in practice. 
Indeed, there is little guidance available in the literature regarding what relative strengths and weaknesses of existing approaches are (Rogerson \& Fidler, 1994). Also many techniques have been advocated for use within the SISP process (J Ward, Griffiths, \& Whitmore, 2002), including the definition and the analysis of the critical success factors (CSFs), SWOT analysis (strengths, weaknesses, opportunities and threats) and valuechain analysis (VCA).

Some organisations, which specialise in information technologies and their applications, have coupled together different methodologies resulting in a complete SISP methodology such as the work by Min et al. (1999) proposing an integrated approach toward strategic information systems planning (Min, Suh, \& Kim, 1999).

Several studies also have focused on SISP approaches e.g. by following Mintsberg's models in his book: the rise and fall of strategic planning (Mintzberg, 2000), the stage of growth analysis which relates to Nolan's work (Gibson \& Nolan, 1974) or by invoking the Organisation's Theory in order to obtain an organisational fit for IS (Burn, 1991). Through the comprehensive studies and practices of SISP, many methodologies are being applied in order to perform SISP processes, therefore organisations may need a set of criteria to better understand different methods, techniques, and tools to choose the proper one based on their requirements (Basahel, 2009; Basahel \& Irani, 2009).

\section{A FRAMEWORK TO CLASSIFY SISP METHOOLOGIES}

In this paper, we firstly introduce a conceptual framework to classify SISP methodologies then we compare some major SISP methodologies using our proposed conceptual framework (as demonstrated in Table 2 in the appendix).

There are different frameworks to evaluate and classify IS development methodologies such as NIMSAD (Jayaratna, 1986), DESMET (Kitchenham, Linkman, \& Law, 1996), and Avison and Fitzgerald's framework (Avison \& Fitzgerald, 2006; Avison \& Fitzgerald, 2003) however there is only a few attempts to classify and compare IS planning methodologies (Basahel, 2009; Basahel \& Irani, 2009; Rogerson \& Fidler, 1994).
Avison and Fitzgerald's framework has the right level of abstraction and generality and could be mapped and adjusted in order to also evaluate and classify IS planning methodologies. According to the General System Theory (GST) (Von Bertalanffy, 1968), models, principles, and laws exist that apply to generalised systems or their subclasses, independent from their specific kind, the nature of their sub-elements, and the relationships among them.

Therefore, by looking at Avison and Fitzgerald's framework as a 'system' of comparison, it is possible to generalise this framework and adjust it (from the IS development level) to the IS planning level. This adjusted conceptual framework will be then used as a guide to choose a relevant SISP methodology when planning for information systems. This conceptual framework is introduced in the following sections (2.1 to 2.7):

\subsection{Fundamental Philosophy}

Fundamental philosophy is a vision upon which the methodology has been established and forms the approach of problem solving. This criterion considers SISP methodologies as problem solving approaches with different fundamental philosophy.

When choosing a methodology, it is important to determine a proper approach towards SISP process and select ones with adaptable approach to the problem with which organisation is facing. It consists of three factors of 1) Paradigm, 2) Methodology objective and 3) Domain and target of the methodology (Avison \& Fitzgerald, 2006; Avison \& Fitzgerald, 2003).

\subsubsection{Paradigm}

Avison and Fitzgerald define paradigm as the problem solving approach of a methodology (Avison \& Fitzgerald, 2006; Avison \& Fitzgerald, 2003). They classify paradigm as science paradigm vs. systems paradigm. Science paradigm explains the world through reductionism, repeatability, refutation and systems paradigm is concerned with whole picture, interrelationships between parts of the whole. (Avison \& Fitzgerald, 2006; Avison \& Fitzgerald, 2003).

In our conceptual framework to classify SISP methodologies, we interpret paradigm as the way a methodology considers 3 distinct factors in the process of problem solving as equivalent of the 
Science and the System paradigms which includes: 1) Technical paradigm, 2) Social paradigm and 3) Socio-technical paradigm. In one side of a spectrum there are methodologies which only look at the technical side of planning for information systems with less attention to the human aspect of IS, while on the other side of this spectrum there are other methodologies that are more human-oriented and consider more of human aspect of information systems when planning for a change in IS planning practice.

In between, there exist other methodologies which combine the advantages of both ends together and form the socio-technical paradigm of planning for information systems (Robson, 1997, 2002).

\subsubsection{Methodology Objectives}

Robson compares and classifies some SISP methodologies based on the following three factors: 1) Efficiency, 2) Effectiveness and 3) Competitive Advantage (Robson, 1997, 2002). One may consider them as the objectives and the main aims of the methodologies.

The aim of some IS planning methodologies is to use information technology and information systems as a means of increasing the efficiency of using organisational resources, while the objective of the second group of IS planning methodologies is to enhance the alignment between IS and business objectives and contributing to the organisations to achieve their strategic business goals and objectives.

The third group of methodologies improves the competitive position of an organisation over its rivals and creates a competitive edge which is not easy to imitate.

\subsubsection{Domain and Target of Methodology}

Robson categorises SISP methodologies according to the organisational level that they are being applied to in the organisations (Robson, 1997, 2002). This criterion is also possible to be mapped to our proposed conceptual framework including the following levels as the domain and target of methodologies: 1) Strategic Business Unit (SBU) level, 2) Corporate level and 3) Business level. Each SISP methodology is applicable to one or more specific organisational level(s). An SISP methodology would target a specific or multiple organisational domains.

\subsection{Modelling Method}

Modeling method of a methodology also derives from its fundamental philosophy and is formed according to the following 3 factors (Avison \& Fitzgerald, 2006; Avison \& Fitzgerald, 2003): 1) Conversation Tool, 2) System Capture and 3) Exhibition of the IS and the business concepts. Modeling method is also an abstraction and the representation of major factors of information systems or organisations and a means of communication.

Modeling methods have four different types (Yaghini, Bourouni, \& Hesam Amiri, 2009): 1) Verbal, 2) Analytical or mathematical, 3) Iconic, pictorial or schematic and 4) Simulations. Each SISP methodology uses one or a combination of these modeling methods to communicate with SISP stakeholders and the project team by creating an abstract representation of the IS and the business problem domain.

\subsection{Tools \& Techniques}

This criterion consists of tools and techniques used by SISP team or Information Systems Department of an organisation when using a specific SISP methodology, e.g. Functional Hierarchy Diagram (FHD) or Data group/Process Matrix in Business Systems Planning methodology (BSP) or Operations Research techniques in Ends-Means Analysis Methodology are some tools and techniques used in SISP process of a specific methodology.

\subsection{Scope}

Scope of a methodology is the breadth and depth of steps that an SISP methodology could cover. Every SISP methodology has its own scope. Some of the methodologies cover all the steps of SISP process and are called 'full-scope methodologies' such as the Integrated Algorithm (Min et al., 1999).

This criterion is also adjusted to the IS planning level using an extended model for the scope of SISP process introduced by Mentzas (Mentzas, 1997) and validated by Newkirk (Newkirk et al., 2003). (see Table 1)

\subsection{Output}

Ultimately, every methodology creates specific outputs that are different according to methodology's unique scope. In fact the output of a methodology depends upon the scope that is mentioned in the previous criterion. 


\subsection{Practice}

The main factor determining practice of an SISP methodology is the development team's a) Business related and b) IS related skills and expertise necessary to apply that specific methodology. For example, BSP requires a high level of expertise and skills in IS field due to the intensity of modeling and designing IS related diagrams and outputs, however it needs a medium level of business related skills and expertise. While Critical Success Factors analysis methodology (CSF) requires a high level of business related knowledge and expertise. Therefore, we classify this criterion in 3 level of expertise in two fields of IS and Business: 1) High expertise, 2) Medium expertise and 3) Low expertise.

\subsection{Product}

The other criterion when assessing and choosing a methodology is the support of the methodology and its product and existence of supporting companies to provide services for the people or customers using the methodology in forms of providing them with related software or consulting services. For example BSP is supported, by IBM Company

\section{COMPARISON OF SISP METHODOLOGIES}

Once the framework is introduced, a set of SISP methodologies could be compared based on the framework. The set of methodologies include: 1) Critical Success Factors Analysis (Rockart, 1982), 2) IBM Business System Planning (Zachman, 1977), 3) Porter's 5 Forces Model (Porter Michael, 1979), 4) SWOT Analysis (Ansoff Igor, 1987; Humphrey, 2004) and 5) Value Chain Analysis (Porter, 1985). Table 2 demonstrates the results of the comparison and the evaluation of these SISP Methodologies. This comparison requires further validation through empirical research which will be accomplished as the next step of the research process. (See table 2 in the Appendix)

\section{CONCLUSIONS}

Since the selection of proper SISP methodology(ies) to develop the IS plan has been proven as a success factor of the IS planning process, the purpose of this theoretical paper was to propose a conceptual framework to classify SISP methodologies to choose the suitable methodology(ies) according to the specific given requirements of an organisation.

Using this proposed conceptual framework, one could compare SISP methodologies to benefit from the mostly suited one(s) to the organisation's requirements and also may combine a set of methodologies in order to cover all SISP phases and tasks in a full scope manner.

The next phase in current research in progress work is to concentrate on the application of this conceptual framework in empirical research in order to assess the validity and reliability of this research's results.

\section{REFERENCES}

Ansoff Igor, H. (1987). Corporate strategy: London, Penguin Books.

Avison, D., \& Fitzgerald, G. (2006). Methodologies for Developing Information Systems: A Historical Perspective. The Past and Future of Information Systems: 1976-2006 and Beyond, 27-38.

Avison, D., \& Fitzgerald, G. (2003). Information systems development: methodologies, techniques and tools.

Banker, R., Kauffman, R., \& Morey, R. (1990). Measuring gains in operational efficiency from information technology: a study of the Positran deployment at Hardee's Inc. Journal of Management Information Systems, 29-54.

Basahel, A. (2009). A FRAMEWORK FOR EVALUATION OF STRATEGIC INFORMATION SYSTEM PLANNING (SISP) TECHNIQUES. Paper presented at the Brunel Business School Doctoral Symposium 2009.

Basahel, A., \& Irani, Z. (2009). Novel Taxonomy For Evaluation Of Strategic Information System Planning (SISP) Techniques. Paper presented at the UK Academy for Information Systems 2009.

Bergeon, F., Buteau, C., Raymond, L. (1991). Identification of strategic information systems opportunities:

applying and comparing two methodologies. MIS Quarterly, 15 (1), 89-103. 
Burch, J. (1990). Planning and building strategic information systems. Journal of Systems Management, 41(7), 21-27.

Burn, J. (1991). Stages of growth in strategic information systems planning (SISP).

Clark Jr, T. (1992). Corporate systems management: an overview and research perspective. Communications of the ACM, 35(2), 75.

Doherty, N., Marples, C., \& Suhaimi, A. (1999). The relative success of alternative approaches to strategic information systems planning: an empirical analysis. The Journal of Strategic Information Systems, 8(3), 263-283.

Gibson, C., \& Nolan, R. (1974). Managing the four stages of EDP growth. Harvard Business Review, 52(1), 7688.

Henderson, J., \& Venkatraman, N. (1993). Strategic alignment: Leveraging information technology for transforming organizations. IBM systems Journal, 32(1), 4-16.

Humphrey, A. (2004). The origins of the SWOT analysis model. SWOT Analysis, by Alan Chapman, www. bussinessballs. com.

Jayaratna, N. (1986). Normative Information Model-Based Systems Analysis and Design (NIMSAD): A framework for understanding and evaluating methodologies. Journal of Applied Systems Analysis, 13, 73-88.

Kitchenham, B., Linkman, S., \& Law, D. (1996). DESMET: A method for evaluating software engineering methods and tools. Keele University.

Lederer, A., \& Sethi, V. (1988). The implementation of strategic information systems planning methodologies. MIS Quarterly, 12(3), 445-461.

Lederer, A., \& Sethi, V. (1996). Key prescriptions for strategic information systems planning. Journal of Management Information Systems, 13(1), 62.

Lederer, A., Sethi, V. (1998). The implementation of strategic information systems planning methodologies. MIS

Quarterly(September), 445-461.

Luftman, J. (2004). Assessing business-IT alignment maturity. Strategies for information technology governance, 99.

Mentzas, G. (1997). Implementing an IS strategy—a team approach. Long Range Planning, 30(1), 84-95.
Min, S., Suh, E., \& Kim, S. (1999). An integrated approach toward strategic information systems planning. The Journal of Strategic Information Systems, 8(4), 373-394.

Mintzberg, H. (2000). The rise and fall of strategic planning: Pearson Education.

Moynihan, T. (1990). What chief executives and senior managers want from their IT departments. MIS Quarterly, 14(1), 15-25.

Newkirk, H., Lederer, A., \& Srinivasan, C. (2003). Strategic information systems planning: too little or too much? The Journal of Strategic Information Systems, 12(3), 201-228.

Peppard, J., \& Ward, J. (2004). Beyond strategic information systems: towards an IS capability. The Journal of Strategic Information Systems, 13(2), 167194.

Porter, M. (1985). Competitive advantage: creating and sustaining superior performance: with a new introduction: Free Pr.

Porter Michael, E. (1979). How competitive forces shape strategy. Harvard Business Review, Boston, 57(2).

Robson, W. (1997). Strategic management and information systems: Pitman London.

Robson, W. (2002). Strategic Management and Information Systems: an Integrated Approach. Financial Times.

Rockart, J. (1982). The changing role of the information systems executive: a critical success factors perspective. Sloan Management Review, 24(1), 3-13.

Rogerson, S., \& Fidler, C. (1994). Strategic information systems planning: Its adoption and use. Information Management and Computer Security, 2, 12-12.

Von Bertalanffy, L. (1968). General system theory: Foundations, development, applications: G. Braziller New York.

Ward, J., Griffiths, P., \& Whitmore, P. (2002). Strategic planning for information systems: Wiley Chichester.

Ward, J., \& Peppard, J. (2002). Strategic planning for information systems: Wiley.

Yaghini, M., Bourouni, A., \& Hesam Amiri, R. (2009). A Framework for Selection of Information Systems Development Methodologies. Computer and Information Science, 2(1), P3.

Zachman, J. (1977). The information systems management system: a framework for planning. ACM SIGMIS Database, 9(3), 13. 


\section{APPENDIX}

Table1. IS planning phases and tasks, source: (Newkirk et al., 2003),(Mentzas, 1997)

\begin{tabular}{|c|c|}
\hline IS planning phases & IS planning tasks \\
\hline $\begin{array}{l}\text { Planning the IS planning process } \\
\text { (i.e. strategic awareness) }\end{array}$ & $\begin{array}{l}\text { Determining key planning issues } \\
\text { Defining planning objectives } \\
\text { Organizing the planning team(s) } \\
\text { Obtaining top management commitment }\end{array}$ \\
\hline $\begin{array}{l}\text { Analyzing the current environment } \\
\text { (i.e. situation analysis) }\end{array}$ & $\begin{array}{l}\text { Analyzing current business systems } \\
\text { Analyzing current organisational systems } \\
\text { Analyzing current information systems } \\
\text { Analyzing the current external business environment } \\
\text { Analyzing the current external IT environment }\end{array}$ \\
\hline $\begin{array}{l}\text { Conceiving strategy alternatives (i.e. } \\
\text { strategy conception) }\end{array}$ & $\begin{array}{l}\text { Identifying major IT objectives } \\
\text { Identifying opportunities for improvement } \\
\text { Evaluating opportunities for improvement } \\
\text { Identifying high level IT strategies }\end{array}$ \\
\hline $\begin{array}{l}\text { Selecting strategy (i.e. strategy } \\
\text { formulation) }\end{array}$ & $\begin{array}{l}\text { Identifying new business processes } \\
\text { Identifying new IT architectures } \\
\text { Identifying specific new projects }\end{array}$ \\
\hline $\begin{array}{l}\text { Planning strategy implementation } \\
\text { (i.e. strategy implementation } \\
\text { planning) }\end{array}$ & $\begin{array}{l}\text { Identifying priorities for new projects } \\
\text { Defining change management approach } \\
\text { Defining action plan } \\
\text { Evaluating action plan } \\
\text { Defining follow-up and control procedure }\end{array}$ \\
\hline
\end{tabular}


Table 2: Evaluation and classification of some of the major SISP Methodologies based on the conceptual framework.

\begin{tabular}{|c|c|c|c|c|c|}
\hline Criteria $\quad$ Methodology & $\begin{array}{l}\text { CSF } \\
\text { Analysis }\end{array}$ & BSP & $\begin{array}{l}\text { Porter's } \\
5 \quad \text { Forces } \\
\text { Model }\end{array}$ & $\begin{array}{l}\text { SWOT } \\
\text { Analys } \\
\text { is }\end{array}$ & $\begin{array}{l}\text { Value } \\
\text { chain } \\
\text { Analysis }\end{array}$ \\
\hline \multicolumn{6}{|l|}{ Planning the IS planning process } \\
\hline Determining key planning issues & $\checkmark$ & $\checkmark$ & & & \\
\hline Defining planning objectives & $\checkmark$ & $\checkmark$ & & & \\
\hline Organizing the planning team(s) & & $\checkmark$ & & & \\
\hline Obtaining top management commitment & $\checkmark$ & $\checkmark$ & & $\checkmark$ & \\
\hline \multicolumn{6}{|l|}{ Analyzing the current environment } \\
\hline Analyzing current business systems & $\checkmark$ & $\checkmark$ & & $\checkmark$ & $\checkmark$ \\
\hline Analyzing current organisational systems & $\checkmark$ & $\checkmark$ & & $\checkmark$ & $\checkmark$ \\
\hline Analyzing current information systems & $\checkmark$ & $\checkmark$ & & $\checkmark$ & $\checkmark$ \\
\hline $\begin{array}{l}\text { Analyzing the current external business } \\
\text { environment }\end{array}$ & $\checkmark$ & $\checkmark$ & $\checkmark$ & $\checkmark$ & $\checkmark$ \\
\hline $\begin{array}{l}\text { Analyzing the current external IT } \\
\text { environment }\end{array}$ & $\checkmark$ & $\checkmark$ & $\checkmark$ & $\checkmark$ & \\
\hline \multicolumn{6}{|l|}{ Conceiving strategy alternatives } \\
\hline Identifying major IT objectives & $\checkmark$ & $\checkmark$ & & $\checkmark$ & $\checkmark$ \\
\hline Identifying opportunities for improvement & $\checkmark$ & $\checkmark$ & $\checkmark$ & $\checkmark$ & $\checkmark$ \\
\hline Evaluating opportunities for improvement & & $\checkmark$ & $\checkmark$ & $\checkmark$ & $\checkmark$ \\
\hline Identifying high level IT strategies & $\checkmark$ & $\checkmark$ & $\checkmark$ & $\checkmark$ & \\
\hline \multicolumn{6}{|l|}{ Selecting strategy } \\
\hline Identifying new business processes & & $\checkmark$ & & & $\checkmark$ \\
\hline Identifying new IT architectures & & $\checkmark$ & & & \\
\hline Identifying specific new projects & & $\checkmark$ & $\checkmark$ & $\checkmark$ & $\checkmark$ \\
\hline Identifying priorities for new projects & & $\checkmark$ & & $\checkmark$ & \\
\hline \multicolumn{6}{|l|}{ Planning strategy implementation } \\
\hline Defining change management approach & & $\checkmark$ & & & \\
\hline Defining action plan & & $\checkmark$ & & & \\
\hline Evaluating action plan & & $\checkmark$ & & & \\
\hline Defining follow-up and control procedure & & $\checkmark$ & & & \\
\hline
\end{tabular}


Table 2 (Continued): Evaluation and classification of some of the major SISP Methodologies based on the conceptual framework.

\begin{tabular}{|c|c|c|c|c|c|c|}
\hline \multicolumn{2}{|c|}{ Methodology } & \multirow{2}{*}{$\begin{array}{c}\text { CSF Analysis } \\
\begin{array}{c}\text { Socio- } \\
\text { technical }\end{array}\end{array}$} & \multirow{2}{*}{$\begin{array}{c}\text { BSP } \\
\begin{array}{c}\text { Socio- } \\
\text { technical }\end{array}\end{array}$} & \multirow{2}{*}{$\begin{array}{c}\text { Porter's } 5 \\
\text { Forces } \\
\text { Model } \\
\begin{array}{c}\text { Socio- } \\
\text { technical }\end{array}\end{array}$} & \multirow{2}{*}{$\begin{array}{c}\text { SWOT } \\
\text { Analysis } \\
\begin{array}{c}\text { Socio- } \\
\text { technical }\end{array}\end{array}$} & \multirow{2}{*}{$\begin{array}{c}\begin{array}{c}\text { Value Chain } \\
\text { Analysis }\end{array} \\
\begin{array}{c}\text { Socio- } \\
\text { technical }\end{array}\end{array}$} \\
\hline \multirow{3}{*}{ 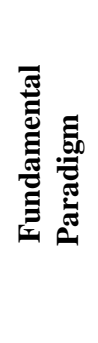 } & Paradigm & & & & & \\
\hline & Objectives & Effectiveness & Efficiency & Effectiveness & Effectiveness & $\begin{array}{c}\text { Efficiency/ } \\
\text { Effectiveness }\end{array}$ \\
\hline & Domain & $\begin{array}{l}\text { Business/ } \\
\text { Corporate/ } \\
\text { SBU }\end{array}$ & Corporate & $\begin{array}{l}\text { Corporate/ } \\
\text { SBU }\end{array}$ & $\begin{array}{l}\text { Business/ } \\
\text { Corporate/ } \\
\text { SBU }\end{array}$ & $\begin{array}{l}\text { Business/ } \\
\text { Corporate/ } \\
\text { SBU }\end{array}$ \\
\hline \multicolumn{2}{|c|}{ Modelling Method } & $\begin{array}{l}\text { Verbal } \\
\text { Analytical or } \\
\text { mathematical }\end{array}$ & $\begin{array}{l}\text { Verbal, } \\
\text { Iconic, } \\
\text { pictorial or } \\
\text { schematic }\end{array}$ & $\begin{array}{c}\text { Verbal } \\
\text { Analytical or } \\
\text { mathematical } \\
\text {, Iconic, } \\
\text { pictorial or } \\
\text { schematic }\end{array}$ & $\begin{array}{c}\text { Verbal } \\
\text { Analytical or } \\
\text { mathematical, } \\
\text { Iconic, } \\
\text { pictorial or } \\
\text { schematic }\end{array}$ & $\begin{array}{l}\text { Verbal } \\
\text { Analytical, } \\
\text { Iconic, } \\
\text { pictorial or } \\
\text { schematic }\end{array}$ \\
\hline \multicolumn{2}{|c|}{$\begin{array}{l}\text { Tools and } \\
\text { Techniques }\end{array}$} & $\begin{array}{c}\text { Delphi } \\
\text { Technique, } \\
\text { Pareto } \\
\text { Analysis, } \\
\text { Fish Bone } \\
\text { Diagram, } \\
\text { Drawing } \\
\text { Tools, } \\
\text { Mathematical } \\
\text { Methods }\end{array}$ & $\begin{array}{l}\text { FHD,ERD,DF } \\
\text { D, Process/ } \\
\text { Organisation } \\
\text { Matrix, Data } \\
\text { group/ Process } \\
\text { Matrix, } \\
\text { System/ } \\
\text { Process \& etc. }\end{array}$ & $\begin{array}{c}\text { Schematic } \\
\text { Tools, } \\
\text { Mathematical } \\
\text { Tools }\end{array}$ & $\begin{array}{c}\text { Action } \\
\text { Diagram, } \\
\text { Mathematical } \\
\text { Methods }\end{array}$ & $\begin{array}{l}\text { Action } \\
\text { Diagram, } \\
\text { Analytical } \\
\text { Diagram }\end{array}$ \\
\hline \multicolumn{2}{|r|}{ Output } & $\begin{array}{l}\text { Information } \\
\text { Flow of SBUs } \\
\text { of the } \\
\text { Organisation, } \\
\text { Information } \\
\text { reflecting the } \\
\text { KPIs \& CSFs } \\
\text { of } \\
\text { effectiveness } \\
\text { of SBUs }\end{array}$ & $\begin{array}{c}\text { Information } \\
\text { Architecture, } \\
\text { Information } \\
\text { Systems } \\
\text { Architecture, } \\
\text { Architecture } \\
\text { of Application } \\
\text { Software, } \\
\text { Hardware and } \\
\text { Network } \\
\text { Infrastructure, } \\
\text { Project } \\
\text { implementatio } \\
\text { n Priorities }\end{array}$ & $\begin{array}{c}\text { Opportunities } \\
\text { for } \\
\text { Information } \\
\text { Systems } \\
\text { Aligned with } \\
\text { Corporate } \\
\text { Competitive } \\
\text { Strategy in } \\
\text { the } \\
\text { Competitive } \\
\text { Environment } \\
\text { of } \\
\text { Organisation }\end{array}$ & $\begin{array}{c}\text { Strategic } \\
\text { alternatives } \\
\text { for } \\
\text { Information } \\
\text { Systems } \\
\text { Aligned with } \\
\text { Corporate } \\
\text { Competitive } \\
\text { Strategy }\end{array}$ & $\begin{array}{l}\text { A big Picture } \\
\text { of Information } \\
\text { systems } \\
\text { required in the } \\
\text { Value chain of } \\
\text { organization }\end{array}$ \\
\hline & Practice & $\begin{array}{c}\text { Low IS /High } \\
\text { Business }\end{array}$ & $\begin{array}{l}\text { High IS } \\
\text { /Medium } \\
\text { Business }\end{array}$ & $\begin{array}{l}\text { Medium IS } \\
\text { /High } \\
\text { Business }\end{array}$ & $\begin{array}{c}\text { Low IS /High } \\
\text { Business }\end{array}$ & $\begin{array}{l}\text { Medium IS } \\
\text { /High } \\
\text { Business }\end{array}$ \\
\hline \multicolumn{2}{|c|}{ Supporting Product } & - & $\begin{array}{l}\text { IBM } \\
\text { Company, } \\
\text { System } \\
\text { Architect }\end{array}$ & - & - & - \\
\hline
\end{tabular}

